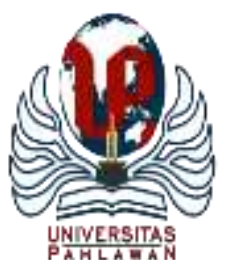

Edukatif : Jurnal Ilmu Pendidikan Volume 4 Nomor 1 Tahun 2022 Halm 19 - 27 EDUKATIF: JURNAL ILMU PENDIDIKAN

Research \& Learning in Education

https://edukatif.org/index.php/edukatif/index

\title{
Analisis Keefektifan Pembelajaran Online di Masa Pandemi Covid-19 pada Mahasiswa Pendidikan Matematika
}

\author{
Agnes Pendy $^{1 凶}$, Lely Suryani², Hilaria Melania Mbagho ${ }^{3}$ \\ Universitas Flores, Indonesia ${ }^{1,2,3}$ \\ E-mail : agnespendy@gmail.com ${ }^{1}, \underline{\text { lelypane@ gmail.com }}{ }^{2}, \underline{\text { hilariambagho130178@ gmai.com }}^{3}$
}

\begin{abstract}
Abstrak
Pandemi Covid-19 telah mempengaruhi seluruh aspek kehidupan manusia, termasuk dunia pendidikan. Oleh karena itu untuk memutus rantai covid 19 salah satu cara dengan social distancing, maka pemerintah memutuskan untuk belajar dari rumah. Banyak platform digital yang bisa digunakan untuk belajar dari rumah, salah satunya adalah pembelajaran $E$ learning. Tujuan penelitian ini adalah mendapatkan informasi tentang keefektifan proses pembelajaran online dimasa pandemi Covid-19. Penelitian ini menggunakan metode kualitatif eksploratif dengan pendekatan induktif. Responden dalam penelitian ini sebanyak 47 orang mahasiswa Program Studi Pendidikan Matematika Universitas Flores pada Semester genap tahun ajaran 2020/2021. Hasil penelitian menunjukkan bahwa 53.2\% dosen menggunakan e-learning, Interaksi mahasiswa lebih mudah akrab saat pembelajaran online sebesar $51.1 \%$, mahasiswa merasa sulit dalam melakukan diskusi tentang materi pembelajaran sebesar $36.2 \%$, sebanyak $31,9 \%$ Pembelajaran online membantu mahasiswa dalam memahami materi pembelajaran. Pembelajaran yang dilaksanakan oleh dosen menyenangkan sebesar 42.6\%, sehingga mahasiswa merasa puas dengan pembelajaran online yang telah dilaksanakan oleh para Dosen dengan persentase sebesar $38.3 \%$. oleh karena itu mahasiswa menyatakan bahwa pembelajaran online efektif sebesar $29.8 \%$. Fasilitas Hp mahasiswa yang menjadi salah satu kendala yang mendasar untuk tidak terdukungnya proses pembelajaran online dengan persentase sebesar $34 \%$.
\end{abstract}

Kata Kunci: Keefektifan Belajar ; Covid 19; E-Learning.

Abstract

The Covid-19 pandemic has affected all aspects of human life, including the world of education. Therefore, to break the chain of covid 19, one way is by social distancing, the Government has decided to learn from home. There are many digital platforms that can be used to learn from home, one of which is E-learning. The purpose of this study was to obtain information about the effectiveness of the online learning process during the Covid-19 pandemic. This study uses an exploratory qualitative method with an inductive approach. The respondents in this study were 47 students of the Mathematics Education Study Program at the University of Flores in the even semester of the 2020/2021 academic year. The results show that 53.2\% of lecturers use e-learning, student interactions are easier to get along with when learning online by $51.1 \%$, students find it difficult to discuss about learning materials by $36.2 \%$, as much as $31.9 \%$ Online learning helps students understand learning materials. The learning carried out by the lecturers was fun by $42.6 \%$, so that students were satisfied with the online learning that had been carried out by the lecturers with a percentage of $38.3 \%$. Therefore, students stated that online learning was $29.8 \%$ effective. The student cell phone facility is one of the fundamental obstacles for the unsupported online learning process with a percentage of $34 \%$.

Keywords: Learning effectiveness; Covid 19; E-Learning

Copyright (c) 2022 Agnes Pendy, Lely Suryani, Hilaria Melania Mbagho

$\triangle$ Corresponding author

Email : agnespendy@gmail.com .

DOI : https://doi.org/10.31004/edukatif.v4i1.1661

ISSN 2656-8063 (Media Cetak)

ISSN 2656-8071 (Media Online)

Edukatif : Jurnal Ilmu Pendidikan Vol 4 No 1 Tahun 2022 p-ISSN 2656-8063 e-ISSN 2656-8071 


\section{PENDAHULUAN}

Pengaruh dari pandemi Covid-19 berdampak di hampir seluruh aspek kehidupan manusia dikarenakan banyak pembatasan sosial yang dilakukan oleh pemerintah untuk menekan penyebaran virus ini. Pendidikan adalah salah satu sektor yang sangat terdampak kondisi pandemi ini, terutama pendidikan diperguruan tinggi (Purwanto et al., 2020). Dengan berkembangnya Iptek dan WHO mengeluarkan deklarasi yang mengatakan dengan resmi bahwa virus Corona dengan nama ilmiahnya COVID-19 adalah pandemi global, maka banyak dari negara dengan penderita pandemi ini telah mengambil tindakan demi menyelamatkan warga negaranya. Cara penyeberan dan penularan virus dengan cepat dan telah menyebar hampir ke seluruh negara. Beberapa negara di luar negeri menerapkan kebijakan untuk memberlakukan lockdown dalam rangka mencegah penyebaran virus Corona.

Di Indonesia, pemerintah memberlakukan yang namanya tentang Pembatasan Sosial Bersekala Besar dalam Rangka Percepatan Penanganan Covid 19 (Presiden Republik Indonesia, 2020). Jumlah yang terus meningkat membuat Pemerintah melalui surat edaran Mendikbud nomor 36962/MPK.A/HK/2020 tentang pembelajaran secara daring dan bekerja dari rumah, maka proses pembelajaran dilakukan dengan cara Belajar Dari Rumah (BDR). Upaya pemenuhan hak siswa untuk mendapatkan layanan pendidikan selama pandemi Covid-19 yaitu proses pembelajaran dilaksanakan melalui penyelenggaraan pembelajaran jarak jauh atau secara daring sesuai dengan Surat Edaran Menteri Pendidikan dan Kebudayaan Republik Indonesia Nomor 3 Tahun 2020 Tentang Pencegahan Corona Virus Disease (Covid-19). Semua dilakukan demi menekan penyebaran virus Covid 19. Pemberlakuan sistem tersebut menjadikan aplikasi online seperti zoom cloud meetings (ZCM) dan google class Room sebagai salah satu alternatif.

Pada penelitian sebelumnya oleh Briliannur Dwi et al., (2021) mengatakan bahwa pembelajaran online pada saat pandemi kurang efektif karena kurangnya sarana dan prasarana serta ketidaksiapan edukasi teknologi. Menurut Nur Annisa, (2013) menyatakan bahwa keefektifan pembelajaran adalah keterkaitan antara tujuan dan hasil dari suatu pembelajaran. Ketuntasan hasil pembelajaran menunjukkan tercapainya tujuan pembelajaran yang telah direncanakan sehingga pembelajaran dikatakan efektif. Hal senada diungkapkan oleh Daryanto, (2013) bahwa efektivitas merupakan tingkat pencapaian tujuan pembelajaran. Tingkat pencapaian merupakan ukuran yang harus dicapai siswa dalam pembelajaran. Pencapaian tujuan pembelajaran dapat berupa peningkatan pengetahuan, kecakapan, dan keterampilan. Mengetahui keefektifan suatu pembelajaran merupakan hal penting karena akan memberikan gambaran sejauh mana pembelajaran dapat mencapai tujuan. Oleh karena itu agar siswa dapat mencapai tujuan pembelajaran diperlukan kegiatan pembelajaran inovatif yang memfasilitasi siswa dalam belajar sehingga siswa paham dengan konsep yang disajikan oleh guru. Pembelajaran yang disusun dengan tujuan menggunakan sistem elektronik atau komputer sehingga mampu mendukung proses pembelajaran (Gani, 2014). E-learning adalah suatu sistem atau konsep pendidikan yang memanfaatkan teknologi informasi dalam proses belajar mengajar.

Di Universitas Flores sendiri memiliki aplikasi BDR dengan nama E-learning Uniflor. Tidak hanya di PC atau laptop, aplikasi ini juga bisa diunduh di smartphone. Sehingga mahasiswa yang sebagian besar memiliki perangkat komunikasi smartphone menjadi pendukung dari pemanfaatan perkembangan teknologi internet dalam pembelajaran. Perkembangan dan fungsi pada smartphone diantaranya mampu mendukung komunikasi penggunanya dengan berbagai aplikasi yang tersedia. Semua itu bisa dilakukan kapanpun tanpa perlu membawa alat yang banyak dan berat, cukup memanfaatkan satu smartphone dengan berbagai fasilitas yang dimilikinya. Hal ini dilakukan karena semasa pembelajaran daring banyak mahasiswa yang pulang kerumah masing-masing. Jadi kapanpun mereka dapat mengakses untuk proses pembelajaran. E-Learning telah menjadi salah satu kebututuhan bagi civitas akademika, mengingat baik dosen, mahasiswa maupun institusi pendidikan telah memanfaatkan teknologi komputer dalam kegiatan belajar mengajar dimasa pandemi ini. Namun dari kebijakan yang dikeluarkan tentunya tidak dapat memastikan semuanya akan 
berjalan sebagaimana mestinya disemua kalangan, khusus nya mahasiswa yang tinggal di pedesaan yang kekurangan fasilitas berupa teknologi terpadu guna menunjang proses pembelajaran online. Kurangnya biaya dan fasilitas yang memadai antara dosen dengan mahasiswanya membuat proses pembelajaran online tidaklah seefektif yang diharapkan. Oleh karena itu maka penelit melakukan penelitian untuk melihat Analisis Keefektifan Pembelajaran Online di Masa Pandemi Covid-19 pada Mahasiswa Pendidikan Matematika Universitas Flores

\section{METODE PENELITIAN}

Metode yang digunakan dalam penelitian ini adalah metode penelitian deskkriptif kuantitatif. Kualitatif Eksploratif dengan pendekatan induktif. Metode ini digunakan untuk mendapatkan informasi keefektifan sesitem pembelajaran secara online (Arikunto, 2010). menjelasakan bahwa "penelitian eksploratif merupakan penelitian yang bertujuan untuk menggali secara luas tentang sebab-sebab atau hal-hal yang mempengaruhi terjadinya sesuatu. Lokasi dan Waktu Penelitian ini dilaksanakan di Program studi Pendidikan Matematika Universitas Flores. Penelitian ini akan dilakukan di semester genap 2020/2021. Subjek dalam penelitian ini adalah mahasiswa Pendidikan matematika yang duduk pada semester 2, semester 4 dan semester 6 sebanyak 47 orang.

Model pengumpulan data yang digunakan dalam penelitian ini adalah sebagai berikut: 1 . Wawancara; Dalam penelitian ini, peneliti akan melakukan wawancara dengan subjek mengenai sebaran efektif pembelajaran online yang selama ini berlaku. 2. Observasi; Metode ini digunakan untuk melihat dan mengamati secara langsung keadaan lapangan agar peneliti memperoleh gambaran yang lebih luas tentang permasalah yang diteliti. 3. Dokumentasi; Metode dokumentasi digunakan untuk mengambil data tentang letak geografis lokasi penelitian dan hal yang diperlukan lainnya. 4. Catatan Lapangan; Catatan lapangan ini merupakan sebuah catatan atau goresan dalam sebuah buku yang dilakukan ketika melakukan sebuah penelitian observasi ataupun wawancara pada saat terjun langsung ke lapangan.

Tahap analisis data merupakan suatu tahapan untuk mencari dan menata secara sistematis catatan hasil observasi, wawancara dan data pendukung lainnya untuk lebih memahamkan peneliti atas fenomena yang diteliti. Analisa data dalam penelitian kualitatif adalah upaya yang dilakukan dengan jalan bekerja dengan data, mengorganisasikan serta memilah-milahnya menjadi satuan yang dapat dikelola, mensistematikannya, mencari dan menemukan pola apa yang penting dan apa yang dipelajari dan memutuskan apa yang dapat diceritakan kepada orang lain (Lexy J.Moleong, 2006). Sehubungan dengan penelitian ini maka data-data yang sudah terkumpul melalui observasi, wawancara, dokumentasi maupun catatan lapangan diurutkan dan diorganisasikan dalam kategori atau pokok - pokok bahasan yang untuk selanjutnya diusulkan dan diuraikan sedemikian rupa kemudian dikaitkan dengan teori yang ada. Penelitian kualitatif deskriptif eksploratif yang bertujuan untuk menggambarkan keadaan atau fenomena, karena itu perspektif teoritik yang digunakan dalam penelitian tersebut adalah fenomenologis, artinya berusaha memahami apa makna kejadian bagi pelakunya pada situasi tertentu.

Pada Teknik Keabsahan Data, data yang telah di dapatkan peneliti dengan penjelasan yang berkaitan dengan tema penelitian akan diseleksi oleh peneliti agar tidak terjadi atau meminimalisir kesalahan dalam analisanya untuk menjelaskan uji keabsahan datanya. Pemeriksaan keabsahan merupakan salah satu teknik pemeriksaan keabsahan data itu sendiri. Dalam hal ini peneliti menggunakan tehnik triangulasi. Teknik ini adalah teknik pemeriksaan keabsahan data yang memanfaatklan sesuatu yang lain diluar data itu untuk keperluan pengecekan atau sebagai perbandingan dan melengkapi data yang dibutuhkan. 
DOI: https://doi.org/10.31004/edukatif.v4i1.1661

\section{HASIL DAN PEMBAHASAN PENELITIAN}

\section{E-Learning}

E-Learning merupakan sebuah metode pembelajaran berbasis internet atau belajar online yang harus dijalani semua siswa-siswi hingga mahasiswa-mahasiswa di Indonesia bahkan seluruh wilayah didunia yang terpapar pandemi Covid-19 guna menyambung proses belajar tatap muka yang terkendala karena social distancing atau tidak berkerumun untuk membantu mencegah penyebaran Covid-19. Di Indonesia, sistem elearning bukan lagi sesuatu yang asing, hanya saja tidak semua sekolah pernah menerapkan sistem ini, terutama sekolah-sekolah yang berada didaerah terpencil atau didesa-desa (Hartanto, 2016). Pada dasarnya, elearning memiliki dua tipe yaitu synchronous dan asynchronous. Synchronous berarti pada waktu yang sama. Proses pembelajaran terjadi pada saat yang sama antara dosen dan mahasiswa. Hal ini memungkinkan interaksi langsung antara dosen dan mahasiswa secara online. Dalam pelaksanaan, synchronous training mengharuskan dosen dan mahasiswa mengakses internet secara bersamaan (Hilmiatussadiah, 2020).

Dosen memberikan materi pembelajaran dalam bentuk makalah atau slide presentasi dan peserta didik dapat mendengarkan presentasi secara langsung melalui internet. Mahasiwa juga dapat mengajukan pertanyaan atau komentar secara langsung ataupun melalui chat window. Synchronous training merupakan gambaran dari kelas nyata, namun bersifat maya (virtual) dan semua mahasiwa terhubung melalui internet. Synchronous training sering juga disebut sebagai virtual classroom (Mustakim, 2020). Proses belajar berbasis e-learning mahasiswa-mahasiswi membutuhkan sarana dan prasarana yang mendukung agar pembelajaran dapat berlangsung dan memiliki kualitas pembelajaran yang lebih baik (Briliannur Dwi et al., 2021). Sarana dan prasarana tersebut diantaranya adalah smartphone (handphone pintar), komputer/laptop, aplikasi, serta jaringan internet yang digunakan sebagai media dalam berlangsungnya pembelajaran berbasis e-learning. Namun, tidak semua keluarga/ orang tua mampu memenuhi sarana dan prasana tersebut mengingat status perekonomian yang tidak merata. Sehingga proses pembelajaran berbasis e-learning tidak tersampaikan dengan sempurna (Nuriansyah, 2020). Pemaduan penggunaan sumber belajar tradisional (offline) dan online adalah suatu keputusan demokratis untuk menjembatani derasnya arus penyebaan sumber belajar elektronik (e-learning) dan kesulitan melepaskan diri dari pemanfaatan sumber-sumber belajar yang digunakan dalam ruang kelas. Artinya, e-learning bagaimana pun canggihnya teknologi yang digunakan belum mampu menggantikan pelaksanaan pembelajaran tatap muka karena metode interaksi tatap muka konvensional masih jauh lebih efektif dibandingkan pembelajaran online atau e-learning (Bisri et al., 2009). Selain itu, keterbatasan dalam aksesibilitas Internet, perangkat keras (hardware) dan perangkat lunak (software), serta pembiayaan sering menjadi hambatan dalam memaksimalkan sumber-sumber belajar online (Yaumi, 2018).

\section{Keefektifan Pembelajaran Online}

Rovai dalam (Hamidi, 2020) menyatakan bahwa alat penyampaian bukanlah faktor penentu kualitas belajar, melainkan desain mata pelajaran menentukan keefektifan belajar. Salah satu alasan memilih strategi pembelajaran adalah untuk mengangkat pembelajaran bermakna. Sehingga efektif atau tidaknya pembelajaran dapat diidentifikasi melalui perilaku-perilaku antara pemelajar dan pembelajar. Bagaimana respon pembelajar terhadap apa yang disampaikan oleh pemelajar. Bagaimana respon pebelajar terhadap apa yang disampaikan oleh pembelajar. Hamidi, (2020) menjelaskan persiapan sebelum memberikan layanan belajar merupakan salah satu faktor penentu dalam keberhasilan belajar, terutama pada online learning di mana adanya jarak antara pembelajar dan pemelajar. Pada pemberlajaran ini pembelajar harus mengetahui prinsip- prinsip belajar dan bagaimana pembelajar belajar.

Menteri Pendidikan dan Kebudayaan Republik Indonesia mengeluarkan (Surat Edaran Nomor 4 Tahun 2020). Tentang Pelaksanaan Kebijakan Pendidikan Dalam Masa Darurat Penyebaran Corona virus Disease (Covid-19) yang berlaku untuk seluruh masyarakat yang mengenyam pendidikan di Indonesia. Disamping keharusan belajar dalam jaringan yang menjadi kendala lainnya adalah kurangnya fasilitas penunjang 
pembelajaran online seperti yang dialami beberapa mahasiswa di Fakultas Keguruan dan Ilmu Pendidikan pada Mahasiswa Program studi Pendidikan Matematika di Universitas Flores memang dapat dikatakan sebagai sebuah kendala dalam proses berlangsungnya pembelajaran, namun usaha tetap harus dilakukan semaksimal mungkin. Disisi lain, tingkat semangat belajar murid juga memicu akan efektif atau tidaknya pembelajaran online ini mengingat budaya belajar tatap muka yang masih melekat dalam diri sehingga, selama kegiatan belajar online ini tidak jarang banyak mahasiswa yang merasa jenuh atau bosan, sehingga membuat hasil belajar yang diharapkan tidaklah efektif (Khusniyah \& Hakim, 2019).

Keefektifan media pembelajaran pembelajaran daring berbasis media e-learning ini disebabkan oleh satu faktor utama yaitu terciptanya sistem pembelajaran mandiri. Media pembelajaran yang dikem bangkan tersebut mampu memenuhi semua ciri-ciri bahan instruksional yang dapat digunakan dalam pembelajaran man diri. Seperti yang diungkapkan oleh 20. (Suparman, 2010). ciri-ciri bahan instruksional yang dapat digunakan dalam sistem pembelajaran mandiri, yaitu: (a) self-instructional, yang berarti bahan itu dapat dipelajari sendiri oleh peserta didik; (b) self-explanatory power, yang berarti bahan instruksional itu mampu menjelaskan sendiri karena menggunakan bahasa sederhana dan isinya runtut, tersusun secara sistematis; (c) self-paced learning, yang berarti peserta didik dapat mempelajari bahan instruksional dengan kecepatan yang sesuai dengan dirinya tanpa perlu menunggu peserta didik lain yang lebih lambat; (d) selfcontained, yang berarti bahan instruksional itu lengkap dengan sendirinya sehingga peserta didik tidak perlu tergantung pada bahan lain; (e) individualized learning materials, yang berarti bahan instruksional itu didesain sesuai dengan kemampuan dan karakteristik peserta didik; (f) flexibel and mobile learning materials, yang berarti bahan instruksional itu dapat dipelajari peserta didik kapan saja dan dimana saja; (g) communicative and interactive learning materials, yang berarti bahan instruksional itu didesain sesuai dengan prinsip komunikasi yang efektif dan melibatkan proses interaksi dengan peserta didik; (h) multimedia, computer-based materials, yang berarti bahan isntruksional itu didesain berbasisikan multimedia, termasuk pendayagunaan komputer secara optimal; dan (i) supported by tutorials, and study group yang berarti bahan instruksional itu masih membutuhkan dukungan tutorial (guru) dan kelompok belajar. (Sibuea et al., 2020).

\section{Hasil}

Penelitian dilaksanakan di Universitas Flores pada Program Studi Pendidikan Matematika pada bulan Maret 2021. Jumlah responden sebanyak 47 mahasiswa. Penelitian dilakukan dengan memberikan angket kepada mahasiswa melalui Google form yang berisi 9 pernyataan. Untuk mengetahui seberapa besar efektivitas pembelajaran online, maka peneliti memberikan beberapa pernyataan yang sangat relevan untuk diisi secara jujur oleh responden yang secara sukarela mau mengisi kuisioner yang sudah disiapkan. Berikut ini beberapa pernyataan yang diajukan kepada responden:

Tabel 1. Data hasil survey untuk mengukur keefektifan pembelajaran online

\begin{tabular}{lccccc}
\hline \multicolumn{1}{c}{ INDIKATOR } & STS 1 (\%) & TS 2(\%) & N(\%) 3 & S (\%)4 & SS 5(\%) \\
\hline $\begin{array}{l}\text { Interaksi mahasiswa bersama dosen } \\
\text { lebih mudah akrab saat melakukan } \\
\text { pembelajaran online }\end{array}$ & 6.4 & 21.3 & 51.1 & 12.8 & 8.5 \\
\hline $\begin{array}{l}\text { Pembelajaran online yang } \\
\text { dilaksanakan oleh dosen } \\
\text { menyenangkan }\end{array}$ & 2.1 & 8.5 & 42.6 & 25.5 & 21.3 \\
\hline $\begin{array}{l}\text { Dosen menggunakan aplikasi } \\
\text { pembelajaran online yang berbeda- } \\
\text { beda }\end{array}$ & 8.5 & 17 & 21.3 & 14.9 & 38.3 \\
\hline
\end{tabular}




\begin{tabular}{lccccc}
\hline \multicolumn{1}{c}{ INDIKATOR } & STS 1 (\%) & TS 2(\%) & N(\%) 3 & S (\%)4 & SS 5(\%) \\
\hline $\begin{array}{l}\text { Fasilitas di Universitas Flores } \\
\text { memiliki website khusus untuk } \\
\text { pembelajaran online }\end{array}$ & 2.1 & 4.3 & 17 & 23.4 & 53.2 \\
\hline $\begin{array}{l}\text { Pembelajaran online membantu } \\
\text { mahasiswa dalam memahami materi } \\
\text { pembelajaran sehingga lebih mudah } \\
\text { dipahami }\end{array}$ & 14.9 & 29.8 & 31.9 & 12.8 & 10.6 \\
\hline $\begin{array}{l}\text { Mahasiswa puas dengan pembelajaran } \\
\text { online yang telah dilaksanakan oleh } \\
\text { para Dosen }\end{array}$ & 6.4 & 19.1 & 38.3 & 17 & 19.1 \\
\hline $\begin{array}{l}\text { Fasilitas Hp mahasiswa tidak } \\
\text { mendukung dalam pembelajaran } \\
\text { online }\end{array}$ & 4.3 & 12.8 & 34 & 23.4 & 25.5 \\
\hline $\begin{array}{l}\text { Pembelajaran online membuat } \\
\text { mahasiswa sulit dalam melakukan } \\
\text { diskusi tentang materi pembelajaran }\end{array}$ & 8.5 & 2.8 & 8.5 & 36.2 & 34 \\
\hline $\begin{array}{l}\text { Proses pembelajaran yang dipakai saat } \\
\text { ini efektif dalam mencapai harapan } \\
\text { dari kegiatan belajar }\end{array}$ & 0 & & & & \\
\hline
\end{tabular}

\section{Pembahasan}

\section{Interaksi mahasiswa bersama dosen lebih mudah akrab saat melakukan pembelajaran online}

Berdasar tabel diatas interaksi mahasiswa bersama dosen lebih mudah akrab saat melakukan pembelajaran online dengan presentasi $51,1 \%$, menunjukan bahwa interaksi antara mahasiswa dan dosen berada di skala ke 3 yaitu netral. Penelitian ini tidak sejalan dengan penelitian yang dilakukan oleh Adijaya \& Santosa, (2018), hsil penelitian menunjukkan bahwa 51,85\% mahsiswa menyatakan tidak mudah untuk akrab dengan dosen, dikarenakan jarangnya tatap muka dengan dosen.

\section{Pembelajaran online yang dilaksanakan oleh dosen menyenangkan}

Berdasar tabel diatas pembelajaran online yang dilaksanakan oleh dosen menyenangkan dengan presentasi $42,6 \%$, menunjukan bahwa pembelajaran online yang dilaksanakan oleh dosen menyenangkan dan berada di skala ke 3 yaitu netral. Penelitian ini tidak sejalan dengan penelitian yang dilakukan (Covid- \& Astuti, 2021), hasil penelitian ini menunjukan bahwa tingkat keefektifan pembelajaran daring dimasa pandemi Covid-19 adalah 39,6\%, artinya berada pada ketegori rendah. Beberapa kendala yang ditemukan dalam pelaksanaan pembelajaran daring di masa pendemi Covid-19 adalah: pengajar kesulitan membangun komunikasi dua arah dengan siswa, terjadi miss komunikasi baik antara siswa dengan pengajar, maupun wali siswa dengan pengajar, perangkat pendukung pembelajaran daring kurang memadai, koneksi internet kurang baik, tidak menyenangkan dan motivasi belajar siswa dalam mengikuti pembelajaran menurun.

\section{Dosen menggunakan aplikasi pembelajaran online yang berbeda-beda}

Berdasar tabel diatas Dosen menggunakan aplikasi pembelajaran online yang berbeda-beda dengan presentasi 38,3 \%, menunjukan Dosen menggunakan aplikasi pembelajaran online yang berbeda-beda di skala ke 5 yaitu sangat setuju. Penelitian ini sejalan yang dilakukan oleh Rosali, (2020) bahwa di Jurusan Pendidikan Geografi Universitas Siliwangi Tasik Malaya juga mengyunakan aplikasi yang berbeda- beda 
yakni menggunakan model daring dengan aplikasi berupa : Vclass, meet Unsil, zoom, whatsapp, telegram, google classroom, youtube, facebook, dan messenger. Aplikasi yang berbeda-beda dilakukan oleh dosen dapat digunakan, yang terpenting adalah tujuan pembelajran dapat tercapai.

\section{Fasilitas di Universitas Flores memiliki website khusus untuk pembelajaran online}

Berdasar tabel Fasilitas di Universitas Flores memiliki website khusus untuk pembelajaran online dengan presentasi 53,2 \%, menunjukan bahwa Fasilitas di Universitas Flores memiliki website khusus untuk pembelajaran online dan berada di skala ke 5 yaitu sangat setuju. Aplikasi yang digunakan oleh Universitas Flores adalah Aplikasi e-learning. Aplikasi e-learning ini dapat diakses kapanpun oleh mahasiswa baik menggunakan HP maupun Laptop.

5. Pembelajaran online membantu mahasiswa dalam memahami materi pembelajaran sehingga lebih mudah dipahami

Berdasar tabel diatas Pembelajaran online membantu mahasiswa dalam memahami materi pembelajaran sehingga lebih mudah dipahami dengan presentasi 31,9 \%, menunjukan bahwa Pembelajaran online membantu mahasiswa dalam memahami materi pembelajaran sehingga lebih mudah dipahami dan berada di skala ke 3 yaitu netral dan 29,8\% mahasiswa mengatakan tidak setuju yaitu pada skala 2. Penelitian ini sejalan yang dilakukan oleh Adijaya \& Santosa, (2018), bahwa 33,33\% mahasiswa mengatakan bahwa perkuliahan onlne kurang mendukung suasana belajar. Ini karena sulit sekali mahasiswa bertanya kepada dosen apabila ada kesulitan dalam memahamimateri.

6. Mahasiswa puas dengan pembelajaran online yang telah dilaksanakan oleh para Dosen

Berdasar tabel ditas Mahasiswa puas dengan pembelajaran online yang telah dilaksanakan oleh para Dosen dengan presentasi 38,3 \%, menunjukan Mahasiswa puas dengan pembelajaran online yang telah dilaksanakan oleh para Dosen dan berada di skala ke 3 yaitu netral, penelitian ini sejalan yang dilakukan oleh (Rohimat, 2021) tingkat kepuasan dengan pembelajaran online berada pada kategori netral sebesar 41,5\%.

\section{Fasilitas Hp mahasiswa tidak mendukung dalam pembelajaran online}

Berdasar tabel diatas Fasilitas Hp mahasiswa tidak mendukung dalam pembelajaran online dengan presentasi $34 \%$, menunjukan bahwa Fasilitas Hp mahasiswa tidak mendukung dalam pembelajaran online dan berada di skala ke 3 yaitu netral, penelitian ini sejalan yang dilakukan oleh Hamidi, (2020) dan Suwarto et al.,( 2021). Hasil dari penelitian ini adalah kurang efektifnya pembelajaran online karena faktor kurangnya sarana dan prasarana serta ketidaksiapan edukasi teknologi.

\section{Pembelajaran online membuat mahasiswa sulit dalam melakukan diskusi tentang materi pembelajaran}

Berdasar tabel Pembelajaran online membuat mahasiswa sulit dalam melakukan diskusi tentang materi pembelajaran dengan presentasi $36,2 \%$, menunjukan bahwa Pembelajaran online membuat mahasiswa sulit dalam melakukan diskusi tentang materi pembelajaran berada di skala ke 4 yaitu setuju. Akan tetapi penelitian ini tidak sejalan dengan yang dilakukan oleh Dadang, (2021), hasil penelitian menggambarkan keaktifan mahasiswa berdiskusi dalam pembelajaran e-learning ini mencapai $80 \%$.

\section{Proses pembelajaran yang dipakai saat ini efektif dalam mencapai harapan dari kegiatan belajar}

Berdasar tabel diatas Proses pembelajaran yang dipakai saat ini efektif dalam mencapai harapan dari kegiatan belajar dengan presentasi 29,8,1 \%, menunjukan bahwa Proses pembelajaran yang dipakai saat ini efektif dalam mencapai harapan dari kegiatan belajar dan berada di skala ke 4 yaitu setuju, penelitian ini sejalan yang dilakukan oleh Purniawan \& Sumarni, (2020) yang menyatakan bahwa pembelajaran daring efektif di gunakan di masa pandemic covid 19 dengan kategori baik sebesar $72 \%$. 


\section{KESIMPULAN}

Pembelajaran E-Learning akan terus harus dilakukan mengingat belum tuntas nya wabah Covid-19 di Indonesia dan membantu dalam upaya pencegahan penyebaran Covid-19 sehingga sampai saat ini masih belum ditentukan kapan akan masuk kampus kembali untuk pembelajaran tatap muka. Pemanfaatan teknologi informasi pada pembelajaran online selama pandemi Covid 19 di Fakultas Pendidikan Matematika Univesitas Flores dinilai tidak efektif oleh mahasiswa ditinjau dari pemahaman materi dan penguasaan aplikasi pembelajaran yang berbeda-beda. Akan tetapi masih terdapat kelemahan pembelajaran yaitu fasilitas hp tidak semua mahasiswa mempunyai $\mathrm{hp}$ android tetapi karena diharuskan di situasi pandemi sekarangnya ini sehingga mahasiswa meminta dana di orang tuanya. Dosen memiliki peran yang sangat penting dalam menentukan kesuksesan pembelajaran online ini. Dosen harus membuat metode pembelajaran yang kreatif, inovatif dan rekreatif merangsang mahasiswa untuk rela terlibat aktif dalam pembelajaran online dan merasakan kebermaknaan dari pembelajaran. Kurang nya sarana dan prasarana yang dipengaruhi oleh faktor ekonomi dan ketidaksiapan teknologi juga menjadi suatu hambatan dalam berlangsungnya kegiatan belajar online agar materi agar materi perkuliahan yang disampaikam oleh dosen efektif dan lancar. Sehingga pembelajaran online di masa pandemi sekarang ini menjadi sangat tidak sepenuhnya efektif meskipun para dosen sudah memberikan sebanyak mungkin pengetahuan dan metede pembelajaran yang mudah dipahami mahasiswa tetapi masih saja kurang efektif pembelajaran online dimasa pandemi ini.

\section{DAFTAR PUSTAKA}

Adijaya, N., \& Santosa, L. P. (2018). Persepsi Mahasiswa Dalam Pembelajaran Online. Wanastra, 10(2), 550. Arikunto, S. (2010). Prosedur Penelitian Suatu Pendekatan Praktek. Rineka Cipta.

Bisri, K., Samsudi, S., \& Supraptono, S. (2009). Efektifitas Penggunaan Metode Pembelajaran Elearning Berbasis Browser Based Training Terhadap Prestasi Belajar Siswa Pada Kompetensi Pemeliharaan/Servis Transmisi Manual Dan Komponen. Jurnal Pendidikan Teknik Mesin Unnes, 9(1), 129527.

Briliannur Dwi, C., Amelia, A., Hasanah, U., Putra, A. M., \& Rahman, H. (2021). Analisis Keefektifan Pembelajaran Matematika Online Di Masa Pandemi Covid-19. Teorema: Teori Dan Riset Matematika, 6(2). Https://Doi.Org/10.25157/Teorema.V6i2.5632

Covid-, M. P., \& Astuti, M. (2021). Analisis Efektifitas Pembelajaran Daring Di Sekolah Dasar Pada Abstrak Analysis Of The Effectiveness Of Online Learning At Elementary Schools During Pandemic Covid-19 Abstract. 1 .

Dadang. (2021). Efektivitas Pembelajaran Online Learning Pada Masa Pandemi Covid- 19 Di Fakultas Keguruan Dan Ilmu Pendidikan Universitas Pamulang. Eduka: Jurnal Pendidikan, Hukum, Dan Bisnis, $6(1), 15-24$.

Daryanto. (2013). Inovasi Pembelajaran Efektif. Yrma Widya.

Gani, A. G. (2014). E-Learning Sebagai Peran Teknologi Informasi Dalam Modernisasi Pendidikan. Jurnal Sistem Informasi Universitas Suryadarma, 3(1), 1-19. Https://Doi.Org/10.35968/Jsi.V3i1.52

Hamidi, A. (2020). Workshop Efektivitas Pembelajaran Daring Pada Masa Pandemi Covid 19 Di Prodi Ikor. Jurnal Maenpo: Jurnal Pendidikan Jasmani Kesehatan Dan Rekreasi, 10(2), 109. Https://Doi.Org/10.35194/Jm.V10i2.1124

Hartanto, W. (2016). Penggunaan E-Learning Sebagai Media Pembelajaran. Jurnal Pendidikan Ekonomi, $10(1), 1-18$.

Hilmiatussadiah, K. G. (2020). Hasil Belajar Mahasiswa Pendidikan Ekonomi Dengan Pembelajaran Daring Pada Masa Pandemi Covid-19. Jurnal Pendidikan Ekonomi Indonesia, 1(2), 66-69. 
Khusniyah, N. L., \& Hakim, L. (2019). Efektivitas Pembelajaran Berbasis Daring: Sebuah Bukti Pada Pembelajaran Bahasa Inggris. Jurnal Tatsqif, 17(1), 19-33. Https://Doi.Org/10.20414/Jtq.V17i1.667

Lexy J.Moleong. (2006). Metodologi Penelitian Kualitatif. Remaja Rosdakarya.

Mustakim, M. (2020). Efektivitas Pembelajaran Daring Menggunakan Media Online Selama Pandemi Covid19 Pada Mata Pelajaran Matematika. Al Asma: Journal Of Islamic Education, 2(1), 1. Https://Doi.Org/10.24252/Asma.V2i1.13646

Nur Annisa, E. (2013). Efektivitas Open Ended Approach Untuk Meningkatkan Kreativitas Siswa Dalam Memecahkan Masalah Matematika (Ptk Di Smk Muhammadiyah 1 Sukoharjo). Ssrn Electronic Journal, 1(2), شمارo Http://Www.Eldis.Org/Vfile/Upload/1/Document/0708/Doc23587.Pdf\%0ahttp://Socserv2.Socsci.Mcmas ter.Ca/ Econ/Ugcm/3113/Michels/Polipart.Pdf\%0ahttps://Www.Theatlantic.Com/Magazine/Archive/199 4/02/The-Coming-Anarchy/304670/\%0ahttps://Scholar.Google.It/Scholar?

Nuriansyah, F. (2020). Efektifitas Penggunaan Media Online Dalam Meningkatkan Hasil Belajar Pada Mahasiswa Pendidikan Ekonomi Saat Awal Pandemi Covid-19. Jurnal Pendididikan Ekonomi Indonesia, 1(2), 61-65. Https://Ejournal.Upi.Edu/Index.Php/Jpei/Article/View/28346

Presiden Republik Indonesia. (2020). Peraturan Pemerintah Nomor 21 Tahun 2020 Tentang Pembatasan Sosial Berskala Besar Dalam Rangka Percepatan Penanganan Coronavirus Disease 2019/Covid-19. 2019(022868), 8 .

Purniawan, \& Sumarni, W. (2020). Analisis Respon Siswa Pada Pembelajaran Daring Di Masa Pandemi Covid 19. Seminar Nasional Pascasarjana Unnes, 784-789.

Purwanto, A., Pramono, R., Asbari, M., Santoso, P. B., Wijayanti, L. M., Choi, C. H., \& Putri, R. S. (2020). Studi Eksploratif Dampak Pandemi Covid-19 Terhadap Proses Pembelajaran Online Di Sekolah Dasar. Edupsycouns: Journal Of Education, Psychology And Counseling, 2(1), 1-12. Https://Ummaspul.EJournal.Id/Edupsycouns/Article/View/397

Rohimat, S. (2021). Analisis Keefektifan Pembelajaran Kimia Secara Daring Di Sma Negeri 6 Kota Serang Pada Masa Pandemi Covid-19. Eduproxima: Jurnal Ilmiah Pendidikan Ipa, 3(2), 90-97. Https://Doi.Org/10.29100/Eduproxima.V3i2.2088

Rosali, E. S. (2020). Aktifitas Pembelajaran Daring Pada Masa Pandemi Covid-19 Di Jurusan Pendidikan Geografi Universitas Siliwangi Tasikmalaya. Geography Science Education Journal (Geosee), 1(1), 21 30 .

Sibuea, M. F. L., Sembiring, M. A., \& Agus, R. T. A. (2020). Efektivitas Pembelajaran Daring Berbasis Media Sosial Facebook Dalam Meningkatkan Hasil Belajar. Jurnal Of Science And Social Research, 3(1), 73-77. Http://Jurnal.Goretanpena.Com/Index.Php/Jssr

Suparman. (2010). Gaya Mengajar Yang Menyenangkan Siswa. Pinus Book Publisher.

Surat Edaran Nomor 4 Tahun 2020. (2020). Surat Edaran Nomor 4 Tahun 2020 Tentang Pelaksanaan Kebijakan Pendidikan Dalam Masa Darurat Penyebaran Corona Virus Disease (Covid 19).

Suwarto, S., Rohmatin, N., \& Yamsih, S. (2021). Analisis Keefektifan Pembelajaran Online Di Masa Pandemi Pada Siswa Kelas X Mipa 6 Sma Negeri 1 Tawangsari. Jurnal Pendidikan Surya ..., April, 38-46.

Yaumi, M. (2018). Media Dan Teknologi Pembelajaran. 